\title{
Beneficial effects of non-matched allogeneic cord blood mononuclear cells upon patients with idiopathic osteoporosis
}

\author{
Jun Li ${ }^{1,2}$, Li Zhang ${ }^{3}$, Liang Zhou ${ }^{4}$, Zheng-Ping Y Y ${ }^{5}$, Feng Qi ${ }^{4}$, Bei Liư ${ }^{3}$, Su-Xia Zi ${ }^{3}$, Li Li ${ }^{3}$, Yi Li ${ }^{6}$, San-Bin Wang ${ }^{7}$, \\ Zheng-Jiang Cui ${ }^{8}$ and Xing-Hua Pan ${ }^{1 *}$
}

\begin{abstract}
Background: Immunological arguments and historical examples have shown that treatment with cord blood for non-hematopoietic activities, such as growth factor production and stimulation of angiogenesis, may not require matching or immune suppression.

Methods: To study the benefit of blood mononuclear cell therapy, 8 patients with idiopathic osteoporosis were given intermittent treatments with non-matched allogeneic cord blood mononuclear cells for 3 months. Morning fasting samples were collected for measuring urine $N$ telopeptide of type- 1 collagen, serum bone-specific alkaline phosphatase, and insulin-like growth factor 1 during one-year study.

Results: Clinical response was striking. Serum insulin-like growth factor 1 significantly increased in all patients at 3 months compared with baseline values, from $264.1 \pm 107.0$ to $384.4 \pm 63.1 \mathrm{ng} / \mathrm{mL}(P=0.002)$, with a tendency to return to baseline values at 12 months $(312.9 \pm 75.5 \mathrm{ng} / \mathrm{mL}, P=0.083)$. In contrast, differences in serum bonespecific alkaline phosphatase and urine $N$ telopeptide of type- 1 collagen were not significant at $3(P=0.765$, $P=0.057$ ) or 12 months ( $P=0.889, P=0.122$ ). A beneficial effect on bone density was observed in all patients at the lumbar spine. The mean bone mineral density calculated during therapy $\left(0.6811 \pm 0.1442 \mathrm{~g} / \mathrm{cm}^{2}\right)$ tended higher than baseline values $\left(0.6239 \pm 0.1362 \mathrm{~g} / \mathrm{cm}^{2}, P<0\right)$, and percentage change (median) varied from $8.85 \%$ at 3 months to $7.85 \%$ at one year. All patients are now well after one year.

Conclusions: The findings indicate that for these patients with idiopathic osteoporosis, treatment with cord blood mononuclear cells led to a significant increase in insulin-like growth factor 1 levels, which favors the increase in bone mineral density.
\end{abstract}

Keywords: Osteoporosis, Cord blood mononuclear cells

\section{Background}

Idiopathic osteoporosis is a rare condition that affects both sexes, women before menopause and men up to sixty-five years. Patients have a decreased ability to recover or regenerate bone mineral content, which may result in bone fracture with little trauma. Diagnosis requires the exclusion of all potential causes of secondary osteoporosis. Asian people on average have a lower bone mineral density than other races, yet their bones

\footnotetext{
* Correspondence: lijun199766@126.com

${ }^{1}$ Stem cell, Tissue and Organ Engineering Research Center, Kunming General, Hospital of Chinese People's Liberation Army, Kunming 650032, China Full list of author information is available at the end of the article
}

fracture less easily; human races also differ in the reference values of bone turnover biomarkers.

Inadequate peak bone mass [1] and increased bone loss are probably involved in the pathogenesis of idiopathic osteoporosis [2]. Both phenomena are associated with low concentrations of insulin-like growth factor 1 in serum [3,4] and bone [5]. The causes of low serum insulin-like growth factor 1 levels in patients with idiopathic osteoporosis remain unclear.

Bone regeneration process involving mesenchymal stem cell invasion, chondrogenesis, osteogenesis, and angiogenesis, breaks down during idiopathic osteoporosis. Circulating multipotent stem cells with characteristic of

\section{Biomed Central}


osteogenic ability have raised interest in novel therapies for osteoporosis [6]. Cord blood mononuclear cells consist of hematopoietic and mesenchymal stem cells, endothelial progenitor cells, and immature immunological cells [7]. Preclinical studies have demonstrated the efficacy of cord blood in the treatment of diverse conditions including amyotrophic lateral sclerosis [8], type I diabetes [9], postinfarct regeneration [10], liver failure [11], and cerebral palsy [12]. Under the practice of medicine, some treatment facilities have been using cord blood stem cells without matching [13-17]. In immune competent recipients, nonmatched allogeneic cord blood cells do not elicit graft versus host disease [18-23].

The mesenchymal content of cord blood may explain the tolerogenic capabilities. Cord blood-derived mesenchymal stem cells secrete immune inhibitory cytokines including IL-10 and TGF- $\beta$ [24,25]. Lymphocytes from cord blood, in contrast to adult blood, are generally immature and usually do not secrete as many inflammatory cytokines [18].

For non-hematopoietic applications, the therapeutic activities of the cord blood are mediated by paracrine effect [26]. In these situations permanent graft survival and matched cells are not essential[17]. The aim of this study is to investigate the benefits of intermittent subcutaneous injections of non-matched allogeneic cord blood mononuclear cells in patients with idiopathic osteoporosis, by evaluating bone density.

\section{Methods}

\section{Patient characteristics}

No prisoner or organs from a prisoner were used in the study. Eight Han Chinese patients ( 2 men and 6 women, 36-53 years old) with idiopathic osteoporosis were included in this study, selected patients seen at Kunming General Hospital of Chinese People's Liberation Army. The osteoporosis was considered idiopathic after extensive clinical and laboratory investigation that excluded endocrine disorders and other chronic diseases that could cause bone loss. All men and three women had previous fragility fractures at the time of diagnosis, while the others were considered osteoporotic on bone densitometry. All patients were in stable clinical condition at the time of the study, without 1) prior history of severe allergic reactions; 2) history of, or active, malignancy; 3) active systemic or severe focal infections; 4) cardiac, pulmonary, renal, hepatic or gastrointestinal disease; 5) psychiatric disorder; or 6) any immunodeficiency disease or condition (as these could influence the prognosis and end-point measurements).

The patients received conventional treatments without increase in bone mineral density $\geq 1$ year prior to entering the current study. They were treated from December 2010 to January 2012 at Kunming General Hospital of Chinese People's Liberation Army. The local institutional review board of Kunming General Hospital of the Chinese People's Liberation Army, under the auspices of the National Ministry of Heath, approved application of the technique. Each patient signed an informed consent form before initiation of treatment. A summary of patients' clinical history and the results of the first bone density are shown in Table 1.

\section{Cell processing}

Umbilical cord blood was collected from healthy unrelated full-term uterine-incision delivery donors (who provided written informed consent) in accordance with the sterile procurement guidelines for cord blood. After collection, each blood sample was tested and verified free of communicable diseases including the hepatitis $B$ and $\mathrm{C}$ viruses (HBV and $\mathrm{HBC}$, respectively), human immunodeficiency virus (HIV), alanine aminotransferase (ALT), and syphilis. Testing was performed by a third party laboratory under local government-monitored conditions. Then 2-3 blood samples were mixed together.

Twenty-five milliliters of cord blood was added to $25 \mathrm{~mL}$ of Ficoll-Paque PREMIUM 1.073 (GE Healthcare AB, Uppsala, Sweden, http://www.amersham.com) in every $50 \mathrm{~mL}$ centrifuge tube and then centrifuged $(750 \mathrm{~g}$, $25 \mathrm{~min})$. Mononuclear cells were collected and washed twice in saline. Contaminating erythrocytes were lysed with lysis buffer consisting of injection grade water. The cells were sieved through a 100 eye cell sieve mesh before administration and were injected as quickly as possibly after preparation (cell number $\geq 6 \times 10^{7}$, containing

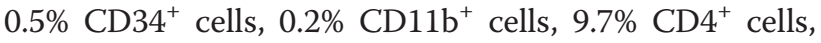
and $8.6 \% \mathrm{CD}^{+} 4^{+}$cell as determined by flow cytometry; cell viability $\geq 96 \%$ ).

Table 1 Summary of clinical history and the first densitometry data

\begin{tabular}{|c|c|c|c|c|c|c|c|c|}
\hline & P1 & $\mathrm{P} 2$ & P3 & P4 & P5 & P6 & P7 & P8 \\
\hline sex and age at study (years) & $M, 53$ & $M, 41$ & $F, 36$ & $F, 39$ & $F, 41$ & $F, 44$ & $F, 42$ & $F, 37$ \\
\hline fragility fractures & $\begin{array}{c}\text { vertebral bodies } \\
\text { at age } 51\end{array}$ & $\begin{array}{c}\text { vertebral bodies } \\
\text { at age } 40\end{array}$ & $\begin{array}{c}\text { vertebral bodies } \\
\text { at age } 33\end{array}$ & $\begin{array}{l}\text { right hip } \\
\text { at age } 36\end{array}$ & no & no & $\begin{array}{l}\text { since age } 33, \\
\text { left humerus }\end{array}$ & no \\
\hline age at first densitometry (years) & 51 & 40 & 33 & 36 & 38 & 41 & 41 & 34 \\
\hline LS BMD at first densitometry $\left(\mathrm{g} / \mathrm{cm}^{2}\right)$ & 0.722 & 0.617 & 0.730 & 0.665 & 0.589 & 0.578 & 0.424 & 0.608 \\
\hline
\end{tabular}

P: Patient, M: male, F: female, LS: lumbar spine; BMD: bone mineral density. 


\section{Cell administration}

Each patient was treated intermittently with $6 \times 10^{7}$ cells/dose, at 4-weeks intervals, 4 times in total, with a follow-up period of 12 months. Twenty milliliters of cell suspension in saline solution $\left(6 \times 10^{7}\right.$ cells $\left./ 20 \mathrm{~mL}\right)$ were subcutaneously injected in several places in the left arm of every patient for convenient observation over 10 to 20 minutes. Injection was repeated 4 times, treatments were separated at 4 week-intervals, and each time with different baby-derived cord blood cells (each time with 2-3 cord blood cell samples for every patient). All patients received 10 samples of cord blood cells in total. After each dose, patients were asked if they experienced discomfort or improvement of syndrome before administering the next dose. No patient received any other medicine, to avoid an interference effect during the therapy schedule (the entire year).

Routine test, insulin-like growth factor 1, bone-specific alkaline phosphatase, $\mathrm{N}$ telopeptide of type- 1 collagen and bone mineral density measurements

Patients returned monthly for clinical examination that included blood pressure and body weight measurements. Blood was drawn after overnight fasting for routine tests. Serum calcium, phosphate, parameters of liver function, lipids, and blood glucose were measured via automated techniques. Fasting morning serum samples were collected for serum insulin-like growth factor 1 and bonespecific alkaline phosphatase, and a sample of the second voided urine was collected for evaluation of the $\mathrm{N}$ telopeptide of type-1collagen at baseline, 3 months and 12 months after the initial treatment. Concentration of insulin-like growth factor 1 was measured with the kit DSL 5600 ACTIVE, EUA. Bone-specific alkaline phosphatase was measured with the kit Alkphaseb, USA. Urinary $\mathrm{N}$-telopeptide of type-1collagen was measured with the kit Osteomark, USA.

Bone mineral density was measured at the lumbar spine using dual-energy X-ray absorptiometry (Expert, Lunar, Madison, WI, USA) at baseline, 3 months and 1 year after the initial treatment. Percent variations in bone mineral density $\geq 1.5 \%$ at the lumbar spine were considered significant. Statistical analysis was performed using the software IBM SPSS 18.0. One-way ANOVA for repeated measures and the paired $t$-test were used to evaluate the differences between levels at baseline and at 3 months, and between baseline and at 1 year. $P$-values $<0.05$ were considered significant.

\section{Results}

Analysis of overall effect for a one year follow-up (beginning with the first administration) showed that treatment with cord blood mononuclear cells via subcutaneous injections was well-tolerated. No allergic or immunological reactions, graft-versus-host disease, or serious adverse effects were observed at the time of injection or while under observation. All patients were free of communicable diseases such as HBV, HCV, HIV, ALT, and syphilis at 3 months. None of the patient had to be withdrawn from the study. Blood pressure and body mass index did not change, nor did the parameters of renal and hepatic functions, serum calcium, phosphate and lipids.

Serum insulin-like growth factor 1 increased in all patients and remained above baseline values during treatment. The mean insulin-like growth factor 1 calculated during the therapy $(348.6 \pm 66.9 \mathrm{ng} / \mathrm{mL})$ tended to be higher than baseline values $(264.1 \pm 107.0 \mathrm{ng} / \mathrm{mL}$, $P=0.008)$. The mean serum insulin-like growth factor 1 increased at 3 months from $264.1 \pm 107.0$ to $384.4 \pm 63.1 \mathrm{ng} / \mathrm{mL}(P=0.002)$ and tended to return to baseline values at 1 year $(312.9 \pm 75.5 \mathrm{ng} / \mathrm{mL}, P=0.083)$. The difference in serum insulin-like growth factor 1 at 3 months and 1 year of the therapy schedule was also significant $(P=0.001)$. Individual values are shown in Table 2.

The mean serum bone-specific alkaline phosphatase levels did not change remarkably: it increased from $16.2 \pm 8.0 \mathrm{U} / \mathrm{L}$ at baseline to $16.5 \pm 6.3 \mathrm{U} / \mathrm{L}$ at 3 months, and to $15.9 \pm 4.2 \mathrm{U} / \mathrm{L}$ at 12 months, but the variations were not significant $(P=0.765, P=0.889$, respectively). The mean urine $\mathrm{N}$ telopeptide of type- 1 collagen decreased from $16.8 \pm 4.3 \mathrm{nMBCE} / \mathrm{mMCr}$ at baseline to $13.8 \pm 2.4 \mathrm{nMBCE} / \mathrm{mMCr}$ at 3 months, and tended to return to baseline values at 12 months $(14.8 \pm 4.0 \mathrm{nMBCE} /$ $\mathrm{mMCr})$, but variations were not significant $(P=0.057$, $P=0.122$, respectively).

Absolute values of bone mineral density at baseline, 3 months and 1 year are shown in Table 3 . A beneficial effect on bone density was observed in all of the patients at the lumbar spine with therapeutic schedules of treatment after either 3 or 12 months, and percentage change (median) varied from $8.85 \%$ at 3 months to $7.85 \%$ at one year.

Table 2 Individual values of insulin-like growth factor 1 (ng/mL) along the therapy

\begin{tabular}{lccc}
\hline & Baseline & 3 months & 1 year \\
\hline IGF-1 (ng/ml) * & & 372 & \\
Patient 1 (male) & 286 & 388 & 390 \\
Patient 2 (male) & 277 & 306 & 286 \\
Patient 3 (male) & 183 & 446 & 232 \\
Patient 4 (male) & 365 & 489 & 359 \\
Patient 5 (male) & 406 & 371 & 428 \\
Patient 6 (male) & 89 & 304 & 280 \\
Patient 7 (male) & 177 & 399 & 212 \\
Patient 8 (male) & 330 & 316 \\
\hline
\end{tabular}

* $p=0.002$ comparing 3 months to baseline, $p=0.083$ comparing 1 year to baseline. 
Table 3 Variation and percent change in lumbar spine bone mineral density $\left(\mathrm{g} / \mathrm{cm}^{2}\right)$

\begin{tabular}{|c|c|c|c|c|c|c|c|c|}
\hline & P 1 & P 2 & P 3 & P 4 & P 5 & P 6 & P 7 & P 8 \\
\hline & (M) & (M) & $(F)$ & $(\mathrm{F})$ & (F) & (F) & $(F)$ & $(F)$ \\
\hline $\begin{array}{l}\mathrm{LS} B M D\left(\mathrm{~g} / \mathrm{cm}^{2}\right) \\
\text { at baseline }\end{array}$ & 0.707 & 0.611 & 0.790 & 0.623 & 0.784 & 0.455 & 0.423 & 0.598 \\
\hline $\begin{array}{l}\text { LS BMD }\left(\mathrm{g} / \mathrm{cm}^{2}\right) \\
\text { at } 3 \text { months }\end{array}$ & 0.761 & 0.668 & 0.884 & 0.650 & 0.846 & 0.493 & 0.495 & 0.672 \\
\hline $\begin{array}{l}\mathrm{LS} \text { BMD }\left(\mathrm{g} / \mathrm{cm}^{2}\right) \\
\text { at } 1 \text { year }\end{array}$ & 0.749 & 0.660 & 0.879 & 0.650 & 0.844 & 0.488 & 0.491 & 0.667 \\
\hline $\begin{array}{l}\% \text { change LS BMD } \\
\text { at } 3 \text { months }\end{array}$ & 7.6 & 9.3 & 11.9 & 4.3 & 7.9 & 8.4 & 17.0 & 12.4 \\
\hline $\begin{array}{l}\text { \% change LS BMD } \\
\text { at } 1 \text { year }\end{array}$ & 5.9 & 8.0 & 11.3 & 4.3 & 7.7 & 7.3 & 16.1 & 11.5 \\
\hline Effect on LS BMD & + & + & + & + & + & + & + & + \\
\hline
\end{tabular}

P: Patient, (M): male, (F): female, LS: lumbar spine, BMD: bone mineral density, $+:$ positive. The effect of cord blood mononuclear cells was considered as positive when the increase in bone mineral density was bigger than $1.5 \%$ at lumbar spine or when patients stopped loosing bone.

To estimate the effect of cord blood mononuclear cells, the bone density after therapy was compared with that at baseline (Figure 1). The mean bone mineral density calculated during the therapy $\left(0.6811 \pm 0.1442 \mathrm{~g} / \mathrm{cm}^{2}\right)$ tended to be higher than baseline values $\left(0.6239 \pm 0.1362 \mathrm{~g} / \mathrm{cm}^{2}, P\right.$ $<0)$. The mean bone mineral density varied from $0.6239 \pm 0.1362$ at baseline to $0.6836 \pm 0.1444(P<0)$ at 3 months and tended to return to baseline values at 1 year $(0.6785 \pm 0.1441, P<0)$; the variation in bone density from 3 months to 1 year of the therapy schedule was also significant $(P=0.005)$. The effect of cord blood mononuclear cells was positive in all patients at the lumbar spine, as showed a net variation of $>1.5 \%$.

\section{Discussion}

Although cord blood-derived cells are superior to bone marrow in terms of growth factor production ability, pluripotency, and immune modulating activity [27], their use has been limited to autologous sources for regenerative applications [17]. In the present study we administrated the latest extracted cells without any other medicine to avoid their interference effect during the whole year. No graft versus host disease or adverse effects were observed after treatment. All patients were free of communicable diseases such as HBV, HCV, HIV, ALT, and syphilis at 3 months. We believe that cord blood mononuclear cells are a viable alternative source of stem cells as they are safely applicable without significant adverse effects.

All patients had a net bone gain of $>1.5 \%$ at the lumbar spine with the therapy in the current study. The variations in serum bone-specific alkaline phosphatase and urine $\mathrm{N}$ telopeptide of type- 1 collagen were not significant at 3 or 12 months. However, the mean urine $\mathrm{N}$ telopeptide of type- 1 collagen decreased at 3 months and tended to return to baseline values at 12 months $(P=0.057, P=0.122)$. The variations in bone turnover marker during therapy usually take place far earlier than those of the bone density. The time points of 3 months and 12 months and the small sample size in this study may contribute to the negative result for $\mathrm{N}$ telopeptide of type- 1 collagen; and the serum bone-specific alkaline phosphatase levels did not change remarkably, indicating that the possible effect of cord blood mononuclear cells is primarily antiresorptive.

We maintained cord blood mononuclear cells during the first 3 months of therapy. The monthly dose of $6 \times 10^{7}$ cord blood mononuclear cells increased insulin-like growth factor 1 levels in all patients at 3 months, and eventual supernormal levels were sustained after 1 year, although the difference at 12 months was not significant. The maintenance of insulin-like growth factor 1 concentrations in the blood correlated with bone density increase in response to cord blood mononuclear cell therapy. Insulin-like growth factor 1 influenced the effect of cord blood mononuclear cells on bone. The data suggest that cord blood mononuclear cells contributed to the increase

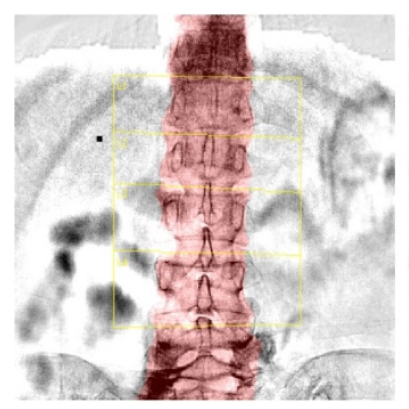

A

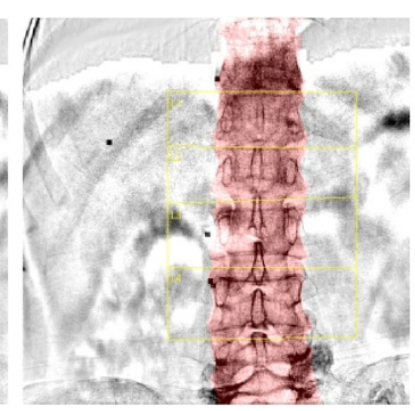

B

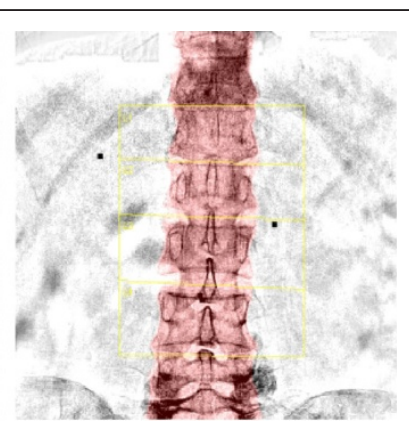

C

Figure 1 The lumbar spine (L2-L4) bone mineral density of patient 7 at baseline. A, The lumbar spine (L2-L4) bone mineral density of patient 7 at baseline. B, The lumbar spine (L2-L4) bone mineral density of patient 7 at 3 months. C, The lumbar spine (L2-L4) bone mineral density of patient 7 at 1 year. 
in insulin-like growth factor 1 concentrations in blood during the treatment, thus favoring bone mineral density increase. Insulin-like growth factor 1 response to cord blood mononuclear cells probably contributed to the normalization of bone formation. It initializes bone remodeling cycles with a relatively greater enhancement of bone density, probably explaining the further increase in bone density observed in this study after stopping cord blood mononuclear cells in patients with idiopathic osteoporosis. As a consequence, the expected beneficial effect of cord blood mononuclear cells on bone density already was evident after the first year.

The difference in bone density between 3 months and 1 year of the therapy schedule was significant $(P=0.005)$. An attenuated positive effect on lumbar spine bone density was seen after 1 year, as insulin-like growth factor 1 was maintained above baseline values, although the difference in insulin-like growth factor 1 between baseline and 1 year was not significant. Thus, it is possible that our patients will continue to decrease bone density in the following year.

Although cord blood stem cells can differentiate into diverse cell lineages [28], the injected cells stimulate the intrinsic stem cells to help them proliferate and differentiate [29]. Not the replacement of injured tissue by transdifferentiation of stem cells, but the paracrine effect promotes the regeneration of damaged tissue [30,31]. We assume that the paracrine effect mainly contributed to our patient's improvements in this study.

Clinical effect of cord blood transplantation depends on the mononuclear cells number, but most cord blood samples do not contain enough stem cells. Increasing cell dose improves engraftment, and partially surmount the influence of human leukocyte antigen disparities. Since 2005, the number of adult patients transplanted with double umbilical cord blood has surpassed the number of adults receiving single cord blood units [32]. In this study we injected the cord blood mononuclear cells expecting transient engraftment and stimulation (paracrine) activity. We administrated the cells from a mixture of several blood samples to guarantee the engraftment of stem cells [33,34]. At least $6 \times 10^{7}$ cells were given each time, enough for cell transplantation, and at the same time we administrated the intermittent treatment with $6 \times 10^{7}$ cells/dose for safe opinion. The repeated administration (4 times) maintained the survival of enough of the stem cells in the patients' bodies. The prolonged infusion intervals (4 weeks) can prevent immune responses induced by repeated administration.

Some studies demonstrated that stem cell therapy can result in functional improvement of the damaged organs in long term period $[35,36]$. Although we cannot guarantee the longer term effect from our study alone, the results from this long term study are encouraging. One limitation of this study is the small sample size, but idiopathic osteoporosis is an uncommon disease. The other limitation is the absence of a placebo-treated control group. However, the patients received conventional treatments without significant increase in bone mineral density prior to entering the current study. In addition, the effect of cord blood mononuclear cells can be considered positive when the increase in bone mineral density is greater than $1.5 \%$ at the lumbar spine, or when patients stop losing bone. For this purpose, each patient could be considered as his own control.

\section{Conclusion}

Our data suggest that intermittent administration of non-matched allogeneic cord blood mononuclear cells therapy exerts beneficial effects on bone mineral density in patients with idiopathic osteoporosis. Insulin-like growth factor 1 initializes bone remodeling cycles with a greater enhancement of bone density, probably explaining the increase in bone density observed in this study.

The importance of this study is that it is the first to investigate the effects of non-matched allogeneic cord blood mononuclear cells on bone mineral density in patients with idiopathic osteoporosis, and the positive effect is encouraging. More studies using this regimen for longer periods are needed to further define the effects of cord blood mononuclear cells on bone density and fracture risk in patients with idiopathic osteoporosis.

\section{Competing interests}

The authors declare that they have no competing interests.

\section{Acknowledgements}

This work was supported by grants from the National Natural Science Fund (311721702011), Yunnan Provincial Science and Technology Department Applied Basic Research Project (2011FZ322), Kunming University Talent Introduction Project (YJL11026), Kunming University Project (XJ11L015), and the Undergraduate Student Groundbreaking Experiment Project (X1112). We thank the staff of Stem Cell, Tissue and Organ Engineering Research Center, Kunming General Hospital of Chinese People's Liberation Army for their valuable technical assistance.

\section{Author details}

${ }^{1}$ Stem cell, Tissue and Organ Engineering Research Center, Kunming General, Hospital of Chinese People's Liberation Army, Kunming 650032, China. ${ }^{2}$ Medical school, Kunming University, Kunming 650214, China. ${ }^{3}$ Department of Gynecology and Obstetrics, Kunming General Hospital of Chinese People's Liberation Army, Kunming 650032, China. ${ }^{4}$ Department of Cardiology, Kunming General Hospital of Chinese People's Liberation Army, Kunming 650032, China. ${ }^{5}$ Department of Labour Hygiene, School of Military Preventive Medicine, Third Military Medical University, Chongqing, China. ${ }^{6}$ Department of Respiratory Medicine, Kunming General Hospital of Chinese People's Liberation Army, Kunming 650032, China. ${ }^{7}$ Department of Hematology and Endocrinology, Kunming General Hospital of Chinese People's Liberation Army, Kunming 650032, China. ${ }^{8}$ Class 1, Grade 2010, Clinical laboratory technology major, Medical school, Kunming University, Kunming 650214, China.

\section{Authors' contributions}

$J\llcorner$ conceived the study, participated in its design and coordination, carried out the clinical treatment and performed the statistical analysis. Li-Z analyzed and interpreted data and drafted the manuscript. Liang-Z, ZY, FQ, BL, SZ, LL, 
$Y L$ carried out the clinical treatment and collected data. SW, ZC analyzed and interpreted data and helped to draft the manuscript. XP conceived the study, participated in its design and coordination and helped to draft the manuscript. All authors read and approved the final manuscript.

Received: 8 February 2012 Accepted: 21 May 2012

Published: 21 May 2012

\section{References}

1. Soyka LA, Fairfield WP, Klibanski A: Hormonal determinants and disorders of peak bone mass in children. J Clin Endocrinol Metab 2000, 85:3951-3963.

2. Pietschmann P, Kudlacek S, Grisar J, Spitzauer S, Woloszczuk W, Willvonseder $\mathrm{R}$, Peterlik M: Bone turnover markers and sex hormones in men with idiopathic osteoporosis. Eur J Clin Invest 2001, 31:444-451.

3. Kurland ES, Chan FKW, Rosen CJ, Bilezikian JP: Normal growth hormone secretory reserve in men with idiopathic osteoporosis and reduced circulating levels of insulin-like growth factor-I. J Clin Endocrinol Metab 1998, 83:2576-2579.

4. Ljunghall $S$, Johannsson AG, Burman P, Kampe O, Lindh E, Karlsson FA: Low plasma levels of IGF-1 in male patients with idiopathic osteoporosis. $J$ Intern Med 1992, 232:59-64.

5. Reed BY, Zerwekh JE, Sakhaee K, Breslau NA, Gorrschalk F, Pak CYC: Serum IGF-1 is low and correlated with osteoblastic surface in idiopathic osteoporosis. J Bone Miner Res 1995, 10:1218-1224.

6. Clines GA: Prospects for osteoprogenitor stem cells in fracture repair and osteoporosis. Curr Opin Organ Transplant 2010, 15(1):73-78.

7. Hutton JF, Gargett T, Sadlon TJ, Bresatz S, Brown CY, Zola H, Shannon MF, D'Andrea RJ, Barry SC: Development of CD4 + CD25 + FoxP3+ regulatory $T$ cells from cord blood hematopoietic progenitor cells. J Leukoc Biol 2009, 85:445-451

8. Garbuzova-Davis S, Willing AE, Zigova T, Saporta S, Justen EB, Lane JC, Hudson JE, Chen N, Davis CD, Sanberg PR: Intravenous administration of human umbilical cord blood cells in a mouse model of amyotrophic lateral sclerosis: distribution, migration, and differentiation. $J$ Hematother Stem Cell Res 2003, 12:255-270.

9. Haller MJ, Wasserfall CH, McGrail KM, Cintron M, Brusko TM, Wingard JR, Kelly SS, Shuster JJ, Atkinson MA, Schatz DA: Autologous umbilical cord blood transfusion in very young children with type 1 diabetes. Diabetes Care 2009, 32:2041-2046.

10. Xing YL, Shen LH, Li HW, Zhang YC, Zhao L, Zhao SM, Xu Q: Optimal time for human umbilical cord blood cell transplantation in rats with myocardial infarction. Chin Med J (Engl) 2009, 122:2833-2839.

11. Moon YJ, Yoon HH, Lee MW, Jang IK, Lee DH, Lee JH, Lee SK, Lee KH, Kim YJ, Eom YW: Multipotent progenitor cells derived from human umbilical cord blood can differentiate into hepatocyte-like cells in a liver injury rat model. Transplant Proc 2009, 41:4357-4360.

12. Harris DT: Non-haematological uses of cord blood stem cells. $\mathrm{Br} J$ Haematol 2009, 147:177-184.

13. Ghen MJ, Roshan R, Roshan RO, Blyweiss DJ, Corso N, Khalili B, Zenga WT: Potential clinical applications using stem cells derived from human umbilical cord blood. Reprod Biomed Online 2006, 13:562-572.

14. Ichim TE, Solano F, Brenes R, Glenn E, Chang J, Chan K, Riordan NH: Placental mesenchymal and cord blood stem cell therapy for dilated cardiomyopathy. Reprod Biomed Online 2008, 16:898-905.

15. Riordan NH, Ichim TE, Min WP, Wang H, Solano F, Lara F, Alfaro M, Rodriguez JP, Harman RJ, Patel AN, Murphy MP, Lee RR, Minev B: Nonexpanded adipose stromal vascular fraction cell therapy for multiple sclerosis. J Trans/ Med 2009, 7:29. doi:10.1186/1479-5876-7-29.

16. Yang WZ, Zhang Y, Wu F, Zhang M, Cho SC, Li CZ, Li SH, Shu GJ, Sheng YX, Zhao N, Tang Y, Jiang S, Jiang S, Gandjian M, Ichim TE, Hu X: Human umbilical cord blood-derived mononuclear cell transplantation: case series of 30 subjects with hereditary ataxia. J Trans/ Med 2011, 9:65. doi:10.1186/1479-5876-9-65

17. Yang WZ, Zhang Y, Wu F, Min WP, Minev B, Zhang M, Luo XL, Ramos F, Ichim TE, Riordan NH, Hu X: Safety evaluation of allogeneic umbilical cord blood mononuclear cell therapy for degenerative conditions. J Trans/ Med 2010, 8:75. doi:10.1186/1479-5876-8-75.

18. Riordan NH, Chan K, Marleau AM, Ichim TE: Cord blood in regenerative medicine: do we need immune suppression? J Transl Med 2007, 5:8. doi:10.1186/1479-5876-5-8.
19. Bhattacharya N: Placental umbilical cord whole blood transfusion: a safe and genuine blood substitute for patients of the under-resourced world at emergency. J Am Coll Surg 2005, 200:557-563.

20. Bhattacharya N: Placental umbilical cord whole blood transfusion to combat anemia in the background of tuberculosis and emaciation and its potential role as an immuno-adjuvant therapy for the underresourced people of the world. Clin Exp Obstet Gynecol 2006, 33:99-104.

21. Bhattacharya N: Placental umbilical cord blood transfusion: a novel method of treatment of patients with malaria in the background of anemia. Clin Exp Obstet Gynecol 2006, 33:39-43.

22. Bhattacharya N: Placental umbilical cord whole blood transfusion to combat anemia in the background of advanced rheumatoid arthritis and emaciation and its potential role as immunoadjuvant therapy. Clin Exp Obstet Gynecol 2006, 33:28-33.

23. Bhattacharya N: A preliminary study of placental umbilical cord whole blood transfusion in under resourced patients with malaria in the background of anaemia. Malar J 2006, 5:20. doi:10.1186/1475-2875-5-20.

24. Liu J, Lu XF, Wan L, Li YP, Li SF, Zeng LY, Zeng YZ, Cheng LH, Lu YR, Cheng JQ: Suppression of human peripheral blood lymphocyte proliferation by immortalized mesenchymal stem cells derived from bone marrow of Banna Minipig inbred-line. Transplant Proc 2004, 36:3272-3275.

25. Togel F, Hu Z, Weiss K, Isaac J, Lange C, Westenfelder C: Administered mesenchymal stem cells protect against ischemic acute renal failure through differentiation-independent mechanisms. Am J Physiol Renal Physiol 2005, 289:F31-F42.

26. Xiao J, Nan Z, Motooka Y, Low WC: Transplantation of a novel cell line population of umbilical cord blood stem cells ameliorates neurological deficits associated with ischemic brain injury. Stem Cells Dev 2005, 14:722-733.

27. Yoo KH, Jang IK, Lee MW, Kim HE, Yang MS, Eom Y, Lee JE, Kim YJ, Yang SK, Jung HL, Sung KW, Kim CW, Koo HH: Comparison of immunomodulatory properties of mesenchymal stem cells derived from adult human tissues. Cell Immunol 2009, 259:150-156.

28. Kong KY, Ren J, Kraus M, Finklestein SP, Brown RH Jr: Human umbilical cord blood cells differentiate into muscle in sjl muscular dystrophy mice. Stem Cells 2004, 22:981-993.

29. Gnecchi M, He H, Liang OD, Melo LG, Morello F, Mu H, Noiseux N, Zhang L, Pratt RE, Ingwall JS, Dzau VJ: Paracrine action accounts for marked protection of ischemic heart by Akt-modified mesenchymal stem cells. Nat Med 2005, 11:367-368.

30. Passier R, van Laake LW, Mummery CL: Stem-cell-based therapy and lessons from the heart. Nature 2008, 453:322-329.

31. Lim JJ, Jang JB, Kim JY, Moon SH, Lee CN, Lee KJ: Human umbilical cord blood mononuclear cell transplantation in rats with intrinsic sphincter deficiency. J Korean Med Sci 2010, 25(5):663-670.

32. Sideri A, Neokleous N, De La Grange PB, Guerton B, Le Bousse Kerdilles MC, Uzan G, Peste-Tsilimidos C, Gluckman E: An overview of the progress on double umbilical cord blood transplantation. Haematologica 2011, 96 (8):1213-1220.

33. Delaney C, Gutman JA, Appelbaum FR: Cord blood transplantation for haematological malignancies: conditioning regimens, double cord transplant and infectious complications. Br J Haematol 2009, 147:207-216.

34. Eldjerou LK, Chaudhury S, de Baisre Leon A, He M, Arcila ME, Heller G, O'Reilly RJ, Barker JN, Moore MA: An in vivo model of double-unit cord blood transplantation that correlates with clinical engraftment. Blood 2010, 116:3999-4006

35. van Laake LW, Passier R, Monshouwer-Kloots J, Verkleij AJ, Lips DJ, Freund C, den Ouden K, van Ward-Oostwaard D, Korving J, Tertoolen LG, van Echteld CJ, Doevendans PA, Mummery CL: Human embryonic stem cell-derived cardiomyocytes survive and mature in the mouse heart and transiently improve function after myocardial infarction. Stem Cell Res 2007, 1:9-24.

36. Mitterberger M, Pinggera GM, Marksteiner R, Margreiter E, Fussenegger $M$, Frauscher F, Ulmer H, Hering S, Bartsch G, Strasser H: Adult stem cell therapy of female stress urinary incontinence. Eur Urol 2008, 53:169-175.

doi:10.1186/1479-5876-10-102

Cite this article as: Li et al:: Beneficial effects of non-matched allogeneic cord blood mononuclear cells upon patients with idiopathic osteoporosis. Journal of Translational Medicine 2012 10:102. 